\title{
Journal of Biology Education
}

UNNES

http://journal.unnes.ac.id/sju/index.php/ujbe

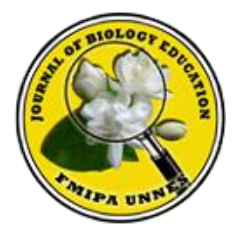

The Implementation of Problem Based Learning with Reguku on the Topic of Immune System in High School

\author{
Eri Kustiani $^{1 \rrbracket}$, Priyantini Widiyaningrum ${ }^{1}$, Ning Setiati $^{2}$
}

Biology Department, FMIPA, Universitas Negeri Semarang, Indonesia

\begin{tabular}{l}
\hline Info articles \\
\hline History Articles: \\
Received : August 2018 \\
Accepted : September 2018 \\
Published : December 2018 \\
\hline Keywords: \\
immune system; problem based \\
learning; reguku.
\end{tabular}

\begin{abstract}
This research aimed to find out the effectiveness of the implementation of problembased learning with Reguku on the topic of immune system for high school to students' attitude of health caring and learning outcomes for high school student. This research uses preexperimental design approach which is helped with conducting one-group pretest-posttest design. There were four kinds of data analyzed in this research: (1) students' score, (2) students' attitude of health caring, (3) students' response and (4) questionnaire of teacher's response to problembased learning with Reguku. Students' learning outcomes was analyzed using N-gain formula and classical completeness test, meanwhile the students' attitude of health caring, students' and teacher's response to problem-based learning with Reguku were analyzed descriptively using percentage. The students' attitude of health caring indicated a good condition which was $76,02 \%$. The data of learning outcomes for student were obtained from the score of posttest, daily activity, discussion sheet, and exercise. Collectively, $83,6 \%$ of the students from both classes passed the minimum passing score of classical completeness test and the increase of $\mathrm{N}$-gain score is in medium criteria $(0,345)$. Both the teachers and the students gave positive response on the implementation of problem-based learning with Reguku. Based on the research findings and discussion, it can be said that problem-based learning with Reguku is effective to be applied on the topic of immune system in SMA N 2 Bae Kudus.
\end{abstract}

(C) 2018 Universitas Negeri Semarang 


\section{INTRODUCTION}

Science learning is a systemmatical work with the purpose of creating, building, and organizing students' understanding of the nature. To optimize the students' ability in performing such tasks, it takes a habit in learning. It can be started with implementing the problem-based learning, taking the natural phenomena in students' surrounding as learning materials. A pilot interview with Biology teachers in SMA N 2 Bae Kudus suggested that immune system is a relatively difficult area for students to master. It is due to the fact that immune system is too broad and contains technical terms, which in turn lowers the students' motivation and achievement. During a formative test in the academic year 2016/2017, 7 out of 31 students in XI MIPA 1 and 9 out of 35 students in XI MIPA 2 passed the minimum score set, that is 70 .

Azka et al. (2016) claimed that teaching learning the immune system has the characteristic that it should be based on problem-solving. The problem-based learning is an approach that provides students with a problem, which later encourages students to think critically about that problem in a real-situated setting. Students are exposed to such problems before they study the related concepts and theory so that they have time to understand and value Biology through classroom activities. Students are supposed to master the critical-thinking skill since it is of great importance when they have to solve problems related to their daily activities (Ayuningrum \& Susilowati, 2015).

Kinaseh et al. (2015) mentioned that basically the problem-based learning is a model that allows students, either individually or collectively, to have their own way in solving the problem during the lesson. Not only does the inquiry provides students with solution to the problems and enhances their knowledge, but also develops their caring for themselves and surroundings.

The learning of immune system is a contextual learning which provides students with how the immune system works within their body. Therefore, it is important for them to study the system and apply their knowledge in everyday activities. The attitude of health-caring is one of conservacy characteristics likely to be implemented during the teaching-learning of immune system. The immune system is an abstract topic since it runs within the human body so that students need a learning media when they are studying the immune system mechanism. This media can be in the form of videos or visual aids. Besides motivating, the use of visual aids encourages students to participate more in the learning process, which in turn may lead to an increase in the students' achievement. Rahayu et al. (2011) suggested that students' participation in classroom organization leads to a deeper understanding of the learning materials studied. However, any forms of visual aids had not been taken into use during the lesson by the students.

According to Arends (2012), there are five phases in problem-based learning: (1) orient students to the problem, (2) organizing students for study, (3) assisting independent and group investigation, (4) developing and presenting artifacts or exhibits, and (5) analyzing and evaluating the problem-olving process. During phase 4, students are developing their visual aids, that is Reguku (Replika Gambaran Umum Kekebalan Tubuh).

Reguku is a visual aid that helps students to visualize how the immune system works. The use of visual aids may contribute to students designing those of their own in group work following the teacher's instructions. After designing the visual aids, students are supposed to gain better understanding of the topic and the learning process becomes more meaningful, that may result in a sharp increase in their achievement. The implementation of PBL with Reguku on the topic of immune system is expected to be effective to the students' attitude of health-caring and academic acheivement. 


\section{RESEARCH METHOD}

This research uses pre-experimental design approach which is helped with conducting onegroup pretest-posttest design. There were two groups of representative samples, XI MIPA 1 and XI MIPA 2, selected using the purposive sampling technique. The independent variable was PBL implementation with Reguku. The dependent variable was students' learning outcomes and attitude of health-caring. There were four kinds of data analyzed in this research: (1) students' score, (2) students' attitude of health caring, (3) students' response and (4) teacher's response to problem-based learning with Reguku. Students' learning outcomes was analyzed using N-gain formula and classical completeness test, meanwhile the students' attitude of health caring, students' and teacher's response to problem-based learning with Reguku were analyzed descriptively using percentage.

This research was divided into two stages (preparation \& experiment). The preparation stage includes: (1) designing the lesson plan, (2) designing the research instuments, (3) testing the instruments, (4) analysing the results of instruments test (validity, reliability, discrimination power, and difficulty level) using ANATES version 4.0.9. The experiment stage includes: (1) pretest, (2) intervention, (3) posttest, (4) collecting the students' and teacher' response to questionnaire. The final stage of this research includes: (1) calculating and analyzing the data collected, (2) reporting the research findings, (4) drawing a conclusion.

\section{RESULTS AND DISCUSSION}

\section{Students' Learning Outcomes}

The students' score was those of posttest score, daily activities, discussion sheet, and exercises. The analysis of students' academic score revealed that a number of students passed the minimum score set, that is 70 . The indivual and collective students' achievement are shown in Table 4.1.

Tabel 1 Students' learning outcomes upon the Implementation of Problem-Based Learning with Reguku on the Topic of Immune System

\begin{tabular}{lcc}
\hline \multicolumn{1}{c}{ Remark } & XI MIPA 1 & XI MIPA 2 \\
\hline Minimum Score & 60 & 63 \\
Maximum Score & 95 & 94 \\
Mean & 77 & 77 \\
Number of Students Passing & 28 & 28 \\
Number of Students Failing & 5 & 6 \\
Collective Achievement Percentage & $84,85 \%$ & $82,35 \%$ \\
Students' Collective Achievement & \multicolumn{2}{c}{$83,6 \%$} \\
\hline
\end{tabular}

The students' score calculation showed that 28 out of 33 students in XI MIPA 1 passed the minimum score with the average score of 77 . It is also presented that 28 out of 34 students in XI MIPA 2 passed the minimum score with the average score of 77 . Collectively, $83,6 \%$ of the students passed the minimum score set, 70. This means the implementation of problem-based learning with Reguku towards students' learning outcomes on the topic of immune system is effective since the collective percentage is above $75 \%$. The $\mathrm{N}$-gain calculation showed that the increase in students' score of cognitive aspect is 0,345 , which is in medium criteria. There is a significant difference between students' pretest and posttest score. It can be said that the implementation of problem-based learning with Reguku towards students' cognitive score on the topic of immune system is effective since the Ngain calculation resulted in medium criteria. These findings, resumed in Figure 4.1, are in line with previuos studies by Fariroh \& Anggraito (2015), Kinaseh et al. (2015) and Putri et al. (2014), that the implementation of PBL leads to an increase in students' achievement. 


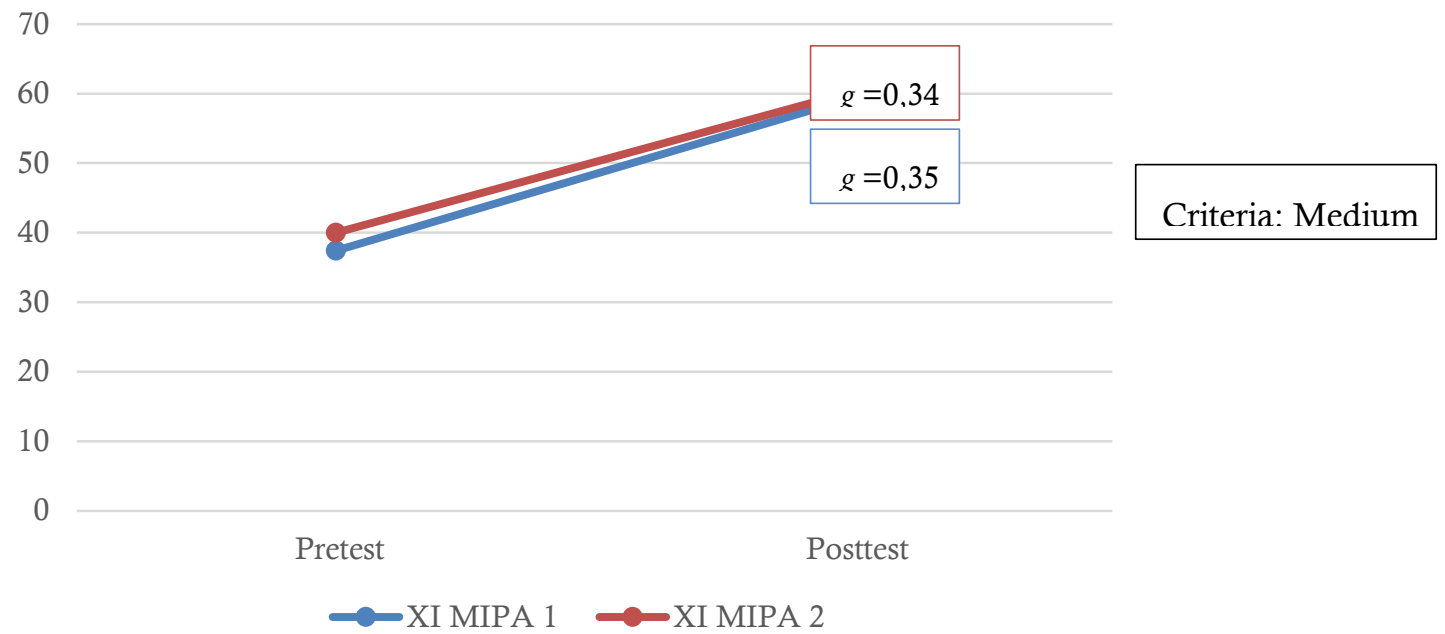

Figure 1 Increase in Students' Cognitive Score According to Pretest and Posttest Result (N-gain)

Problem-based learning helps students to improve their communication and collaboration skills in gathering information and making use of it. A study by Aziz et al. (2014) indicates an increase in students' independency which allows them to take responsibility and initiation of doing scientific research with(out) teacher's guidance. In Hamalik's view (2014), students are more likely to finish a project if they are involved since the initial stage of the project.

The implementation of problem-based learning with Reguku on the topic of immune system has the advantages of being implemented in classroom; 1) students become active during the lesson, 2) students think more critically about any problems, 3) students are likely to gather more information, 4) students are likely to develop their creativity, and 5) students' achievement is increased. These results are in line with Adiga \& Adiga (2015), Dude et al. (2017), Susilowati et al. (2017), and Sutriman (2015) who mentioned that there are benefits of implementing PBL, e.g. improving students' skills of critical and analytical thinking, which in turn increase the students' achievement. These are also in line with researchs by Mulyono et al. (2012) and Wulandari et al. (2017), that suggested the contextually designed learning of Biology affects the students' achievement. Dealing with real objects makes it easier for students to comprehend any concepts in Biology and to expand their thinking capacity

Classroom learning, however, does not always go as expected. The average pretest score of the students of XI MIPA 1 during pretest was 37,42 while during posttest was 59,39, meanwhile, the average score of the students of XI MIPA 2 during pretest was 40 and during posttest was 60,29 . The collective achievement of the two groups is still below the minimum score set (70). This achievement indicates that the students' understanding of the topic is not up to standard. It is probably due to some internal and external factors, as pointed out by Slameto (2010). Examples of the external factors causing the below-standard students' achievement are: 1) it takes much time so that teachers need to consider time allocation for each step in PBL, 2) the learning is only focused on the problem given, 3) time allocated for discussion and presentation is not enough, and 4) teachers have to make sure that group discussion is fair. According to Nugroho et al. (2014), the students' low motivation and participation can affect their achievement. The quality of the learning media can also affect the students' learning outcomes.

\section{Students' Attitude of health-caring}

The students' response to health-caring was collected using a questionnaire. The summary of this data is graded and presented in Table 4.3. 
Table 2 Grading and Summary of the Students' Attitude of health-caring Score upon the Implementation of Problem-Based Learning with Reguku on the Topic of Immune System

\begin{tabular}{|c|c|c|c|}
\hline No & Items & $\begin{array}{l}\text { Average } \\
\text { Score }\end{array}$ & $\%$ \\
\hline 1 & I always wash my hands before I have meals & 3,64 & 91,04 \\
\hline 2 & I consume only nutritious food & 3,48 & 86,94 \\
\hline 3 & I always do physical exercise at least 3 times a week & 3,09 & 77,24 \\
\hline 4 & I always keep my body clean & 3,6 & 89,96 \\
\hline 5 & I always keep my environment clean & 3,36 & 83,96 \\
\hline 6 & I share my beverage with friends using the same straw & 3,45 & 86,19 \\
\hline 7 & I always wear a mask when I am sick & 2,85 & 71,27 \\
\hline 8 & I give no aid to flesh wounds & 2,42 & 60,45 \\
\hline 9 & I am vaccinated against any new diseases & 3 & 75 \\
\hline 10 & I stay away from those who are infected smallpox & 3,18 & 79,48 \\
\hline 11 & I always get enough sleep & 2,98 & 74,63 \\
\hline 12 & I go for my regular medical check-up once a month & 2,52 & 63,06 \\
\hline 13 & I take an immunomodulator to boost my immune system & 2,69 & 67,16 \\
\hline 14 & $\begin{array}{l}\text { I help to promote public health through health campaign } \\
\text { around my neighbourhood }\end{array}$ & 2,67 & 66,79 \\
\hline 15 & $\begin{array}{l}\text { My family members are registered in health insurance } \\
\text { program }\end{array}$ & 3,36 & 83,96 \\
\hline & $\begin{array}{c}\text { Maximum Score } \\
\text { Average Score in Percentage (\%) } \\
\text { Criteria }\end{array}$ & \multicolumn{2}{|c|}{$\begin{array}{c}4 \\
76,02 \\
\text { Good }\end{array}$} \\
\hline
\end{tabular}

As can be seen in Table 4.3, the average score of students' attitude of health-caring in (\%) is 76,02 , categorized as good. This means the implementation of problem-based learning with Reguku is effective to students' attitude of health-caring. In the two groups, the N-gain calculation of students' attitude score resulted in low criteria. It can be said that the implementation of problem-based learning with Reguku towards students' attitude of health-caring score on the topic of immune system is positive. The summary is presented in Figure 2.

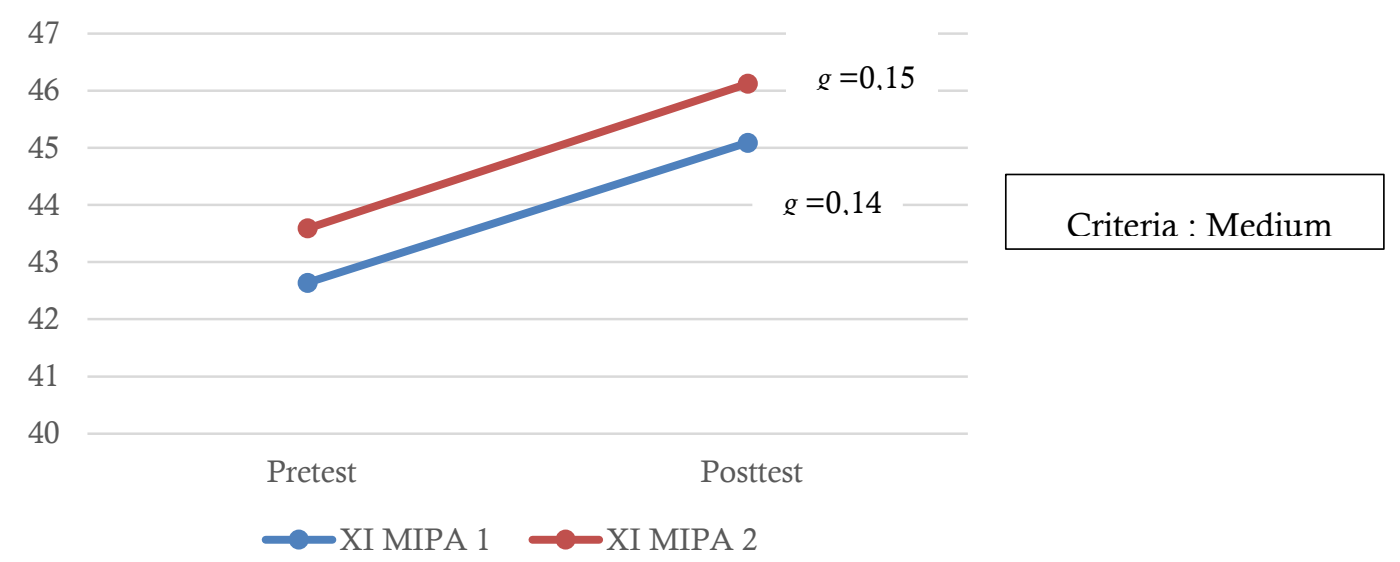

Figure 2 Increase in Students' Attitude Score to Health-Caring (N-gain)

The attitude of health-caring is the way human beings behave consciously that shows respect for their well-being and environment as if it is their responsibilty. In teaching-learning, teachers play an important role in "shaping" the students' attitude. Again in Hamalik's view (2014), teachers are in charge of helping the students to change their attitude into a better one. The change in students' attitude is of affective aspect, which cannot be measured in a short period. But the attitude of health-caring can grow when driven by a learning process that can encourage students to understand the material. Correspond to Fauzi et al (2018) and Kresnawati (2013), the higher the students' score is, the more positive attitude they get. In other words, the students' cognitive understanding of health-caring 
influences their knowledge of problems related to immune system. In this research, the students' attitude score of health-caring is measured using a scale that employs a questionnaire. Usman et al (2017) stated that students are more careful to respond to items in a questionnaire than any other kinds of data collection instruments, and students would take the most reasonable choice that suits them.

\section{Students' Response}

The data of students' response to PBL with Reguku was collected using a questionnaire upon completion of the course. The result is presented in Table 4.3. The result indicates that the implementation of problem-based learning with Reguku had a good response from the two groups with the collective percentage of $79,95 \%$ in the good criteria.

Table 3 Students' Response to the Implementation of Problem-Based Learning with Reguku on the Topic of Immune System upon Completion of the Course

\begin{tabular}{|c|c|c|c|c|c|}
\hline \multirow[b]{2}{*}{ No } & \multirow[b]{2}{*}{ Items } & \multicolumn{2}{|c|}{ Group (\%) } & \multirow[b]{2}{*}{ Mean } & \multirow[b]{2}{*}{ Criteria } \\
\hline & & $\begin{array}{c}\text { XI } \\
\text { MIPA } 1\end{array}$ & $\begin{array}{l}\text { XI MIPA } \\
2\end{array}$ & & \\
\hline 1 & $\begin{array}{l}\text { It is easier for me to understand any } \\
\text { learning materials which done by solving } \\
\text { the problems }\end{array}$ & 77,5 & 80 & 78,75 & Good \\
\hline 2 & $\begin{array}{l}\text { The immune system learning that is done } \\
\text { by solving the problems I face makes me } \\
\text { excited to attend the learning }\end{array}$ & 85 & 85 & 85 & Good \\
\hline 3 & $\begin{array}{l}\text { Immune system learning done by solving } \\
\text { problems which I face makes me want to } \\
\text { know more about those problems }\end{array}$ & 80 & 80 & 80 & Good \\
\hline 4 & $\begin{array}{l}\text { I am motivated to conduct scientific } \\
\text { investigations to find solutions of problems } \\
\text { I face }\end{array}$ & 75 & 77,5 & 76,25 & Good \\
\hline 5 & $\begin{array}{l}\text { Immune system learning done by linking } \\
\text { the problems that I face make my critical } \\
\text { thinking skill about the environment } \\
\text { around me develop }\end{array}$ & 80 & 80 & 80 & Good \\
\hline 6 & $\begin{array}{l}\text { Problem-based learning on immune system } \\
\text { makes me care more about health }\end{array}$ & 80 & 82,5 & 81,25 & Good \\
\hline 7 & $\begin{array}{l}\text { The making of a replica of immune's } \\
\text { general description helps me to understand } \\
\text { more about immune system }\end{array}$ & 80 & 82,5 & 81,25 & Good \\
\hline 8 & Reguku encouraged me to think creatively & 77,5 & 77,5 & 77,5 & Good \\
\hline 9 & $\begin{array}{l}\text { Reguku makes me more active when learn } \\
\text { the immune system }\end{array}$ & 77,5 & 80 & 78,75 & Good \\
\hline 10 & $\begin{array}{l}\text { The immune system learning conducted } \\
\text { by the teacher made me optimistic that I } \\
\text { would get the optimal score on the daily } \\
\text { assessment about immune system }\end{array}$ & 77,5 & 82,5 & 80 & Good \\
\hline & Maximum Score & & & 4 & \\
\hline & Average Score in Percentage (\%) & & & 79,95 & \\
\hline & Criteria & & & Good & \\
\hline
\end{tabular}

\section{Teacher's Response}

The data of teacher's response to PBL with Reguku is summarized in Table 4.4. As shown in Table 4.4, the implementation of problem-based learning with Reguku had a good response from the teacher with the collective percentage of $85 \%$ in the good criteria. 
Table 4 Teacher's Response to the Implementation of Problem-Based Learning with Reguku on the Topic of Immune System

\begin{tabular}{clcccc}
\hline No & \multicolumn{1}{c}{ Items } & Score & $\begin{array}{c}\text { Maximum } \\
\text { Score }\end{array}$ & \% & Criteria \\
\hline 1 & $\begin{array}{l}\text { Implementation of problem-based } \\
\text { learning assisted by teaching aids can } \\
\text { make students easier to understand } \\
\text { immune system }\end{array}$ & 4 & 75 & Good \\
2 & $\begin{array}{l}\text { Presentation of the material is } \\
\text { systematically arranged } \\
\text { Reguku (a replica of the general } \\
\text { description immune) involving students } \\
\text { can make students more creative and } \\
\text { active in the learning }\end{array}$ & 3 & 4 & 100 & Good \\
$\begin{array}{l}\text { Material about learning immune system } \\
\text { by applying problem-based learning can } \\
\text { grow the students attitude of health } \\
\text { caring }\end{array}$ & 3 & 4 & 75 & Good \\
I am interested in applying the learning \\
model of Problem Based Learning \\
assisted by teaching aids in other \\
materials \\
Average Score in Percentage (\%)
\end{tabular}

\section{CONCLUSION}

Based on the research findings and discussion, it can be said that problem-based learning with Reguku is effective to be applied on the topic of immune system in SMA N 2 Bae Kudus. In details, the score of students' attitude of health caring is in a good criteria $(76,02 \%)$. The percentage of students passed the minimum passing score is $83,6 \%$ and the increase of $\mathrm{N}$-gain score is in medium criteria $(0,345)$.

\section{REFRENCES}

Adiga, U \& S. Adiga. 2015. Review Article Problem Based Learning. International Journal of Current Research. 7(6) : 17181-17187

Arends, R. I. 2012. Learning to Teach Ninth Edition. New York: McGraw-Hill,

Ayuningrum, D. \& S. M . E. Susilowati. 2015. Pengaruh Model Problem Based Learning terhadap Keterampilan Berpikir Kritis Siswa SMA pada Materi Protista. Unnes Journal of Biology Education. 4 (2) : 124-133

Azka, S. H. M., D. R. Indriyanti \& T. Widianti. 2016. Keefektifan Media Pembelajaran "Si Imut" Berbasis Masalah Materi Sistem Imun Terhadap Sikap Peka dan Peduli Keselamatan Diri dan Lingkungan Siswa. Unnes Journal of Biology Education. 5 (3) : 237 - 246

Duda, H. J., H. Susilo \& P. Newcombe. 2017. Problem Based Learning Through Laboratory Work and Authentic Assessment: Empowering Critical Thinking Abilities in Indonesia Students. International Journal of Current Multidisciplinary Studies. 3(9) : 806-810

Fariroh, A \& Y. U. Anggraito 2015. Pengembangan Perangkat Pembelajaran Berbasis Problem Based Learning pada Materi Virus Kelas X. Unnes Journal of Biology Education .4 (2) :149-155

Fauzi, M. I., C. Muryani \& S. Santoso. 2018. Hubungan Antara Pengetahuan Lingkungan Hidup dan Prestasi Belajar Geografi dengan Sikap Peduli Lingkungan pada Siswa SMA Negeri di Kabupaten Karanganyar. Jurnal GeoEco. 4 (1) : 88-99

Hamalik, O. 2004. Psikologi Belajar dan Mengajar. Bandung: Sinar Baru Algensindo

Kinaseh, N. Subekti \& T. A. Pribadi 2015. Pengaruh Model Problem Based Learning Dengan Media Animasi Flash terhadap Hasil Belajar dan Aktivitas Siswa. Unnes Journal of Biology Education. 4 (3) : 317-321

Kresnawati, N. 2013. Korelasi Kualitas Pembelajaran Geografi dan Hasil Belajar terhadap Sikap Peduli Lingkungan Siswa Kelas XII IPS SMAN 1 Ponorogo. Jurnal Pendidikan Humaniora. 1 (3) : 298-303

Mulyono, Y., S. H. Bintari, E. S. Rahayu \& P. Widiyaningrum. 2012. Pengembangan Perangkat Pembelajaran dengan Pendekatan Scientific Skill Teknologi Fermentasi Berbasis Masalah. Lembar Ilmu Kependidikan. $4(1): 20-26$ 
Nugroho, A. S. P., M. Rahayuningsih \& N. Setiati. 2014. Efektivitas Pemanfaatan Penangkaran Kupu-Kupu di Unnes sebagai Sumber Belajar Materi Pertumbuhan dan Perkembangan bagi Siswa SMP Negeri 24 Semarang. Unnes Journal of Biology Education. 3 (1) : 1-9

Putri, A. M, S. Khanafiyah \& H. Susanto, 2014. Penerapan Model Pembelajaran Kontekstual dengan Pendekatan Snowball Throwing untuk Mengembangkan Karakter Komunikatif dan Rasa Ingin Tahu Siswa SMP. Unnes Physisc Education Journal. 3 (1): $54-60$

Rahayu, E., H. Susanto \& D. Yulianti. 2011. Pembelajaran Sains dengan Pendekatan Keterampilan Proses untuk Meningkatkan Hasil Belajar dan Kemampuan Berpikir Kreatif Siswa. Jurnal Pendidikan Fisika Indonesia. $7(2): 106-111$

Slameto. 2010. Belajar dan Faktor-faktor yang Mempengaruhinya. Jakarta: Rineka Cipta

Susilowati, S. M. E., A. Delima \& P. Widiyaningrum. 2017. Model Pembelajaran Problem Based Learning (PBL) berbantuan LKS Kreasi Sistem Respirasi untuk Meningkatkan Hasil Belajar Siswa SMA. Satya Widya. 33(2) : 154-164

Sutirman. 2013. Media \& Model-Model Pembelajaran Inovatif. Yogyakarta : Graha Ilmu

Usman, S. M. E. Susilowati \& P. Widiyaningrum. 2017. Analisis Kesesuaian RPP terhadap Pelaksanaan Pembelajaran Biologi dalam Mengembangkan Keterampilan Berpikir Kritis Siswa. Journal of Innovative Science Education. 6 (2) : 243-251

Wulandari, P. Widiyaningrum \& N. Setiati. 2017. Pengembangan Suplemen Bahan Ajar Biologi Berbasis Riset Identifikasi Bakteri untuk Siswa SMA. Journal of Innovative Sci 